\title{
Congenital Urethral Polyps: A Rare Cause of Bladder Outlet Obstruction in Children
}

\author{
Sumit Dhuria* and William Bhatti \\ Department of Paediatric surgery, Christian medical college \& Hospital, India
}

Submission: November 19, 2016; Published: February 08, 2017

*Corresponding author: Sumit Dhuria, Department of Paediatric surgery, Christian medical college \& Hospital, Ludhiana, Punjab, India 141001, Email: Dr_sumitdhuria@yahoo.co.in

\begin{abstract}
Polypoid mass in the prostatic urethra is uncommon but potentially represents a wide spectrum of different entities, ranging from congenital malformations, benign polyps, premalignant disorders to various malignancies. Congenital urethral polyps are rare entity in infancy. They are congenital benign tumors. Most patients present with acute retention, hematuria or intermittent bladder outlet obstruction. The treatmentof choice is transurethral endoscopic ortransvesical resection. Histological study confirms the diagnosis and theprognosis is excellent. We report a case of an 18 month's old boy who presented with acute urinary retention. There was history of dribbling of urine and excessive crying during micturition. Imaging and endoscopic studies confirmed the presence of a polypoid pedunculated lesion at the bladder base arising from posterior urethra. It was excised by cystostomy because of an unsuccessful cystoscopic removal attempt. Although this is considered a benign lesion with no previous reports of recurrence or malignant behavior, it produces dramatic urinary symptoms in the pediatric population with a wide differential diagnosis. Imaging and endoscopic findings may suggest a malignancy and are not sufficient to render a precise diagnosis, which can only be made by pathologic examination.
\end{abstract}

Keywords: Polyps; Urethra; Hematuria; Congenital; Urinary retention

\section{Introduction}

Congenital urethral polyps cause a variety of symptoms in children. John Hunter is credited with the first documented case of urethral polyp, and Thompson reported the first case in a patient. Congenital urethral polyps are rare with only sporadic reports of a small series of cases [1]. Posterior urethral polyps in children are uncommon, and anterior urethral polyps are even rarer. Nevertheless, anterior urethral polyps are exceptionally reported in the literature [2-5]. These polyps are congenital and occur usually in boys; the average age of presentation is 5.2 years. Polyps in boys mostly arise from the posterior urethra, are usually proximal to the membranous urethra, and present usually as a single tumor, only rarely as multiple separate masses. This benign pathology is supposed to represent a developmental error in the invagination process of the submucosal, glandular portion of the inner zone of the prostate gland [6]. These Congenital urethral polyps are the most common benign mesodermal tumors of the urinary tract. Such lesions can also be called prostatic urethral polyps (in boys), fibroepithelial polyps of the urethra, or benign urethral polyps. Congenital urethral polyps more frequently occur in males and in the posterior urethra; this entity is very rare in females. Congenital urethral polyps should not be confused with the polyps of botryoid sarcoma [7]. The embryologic basis for urethral polyps is not clear; however, it is possible that they may arise from mesonephric remnants [8]. These lesions are benign, pedunculated tumors that arise in the region of the verumontanum in males or mid-urethra in females. In early infancy, they usually cause urethral obstruction. However, in older boys, the main presenting features include hesitancy, diminished stream, incomplete emptying, urinary retention, and sudden painful interruption of urinary stream, dysuria, hematuria, UTI, VUR, and enuresis.

\section{Case Report}

An 18-month-old boy presented with complaint of urinary retention and dribbling of urine for 3 days. Clinical examination revealed no abnormalities. Laboratory assessments were unremarkable, except for 4-5 red blood cells on urine analysis. Cystourethrography (VCUG) revealed normal findings and ultrasonography (USG) showed a round, mobile mass, $22 \times 9 \mathrm{~mm}$ in size at the bladder neck. Cystourethroscopy confirmed the presence of a posterior urethral polyp extending from posterior urethra into the bladder. An attempt to remove it endoscopically 
was unsuccessful, because the polyp had a smooth surface, a tense wall and was floating in the bladder. Therefore, it was excised by cystostomy. Pathologic gross findings consisted of polypoidal greyish white soft tissue measuring $1.5 \times 1 \times 1 \mathrm{~cm}$. Micro- section shows a polyp covered by transitional epithelium which is locally ulcerative, other areas the epithelium is mildly hyperplastic. The stroma is composed of vascular fibro-connective tissue and shows a dense inflammatory infiltrate comprising of neutrophils, lymphocytes, eosinophils and histiocytes (Figure 1).

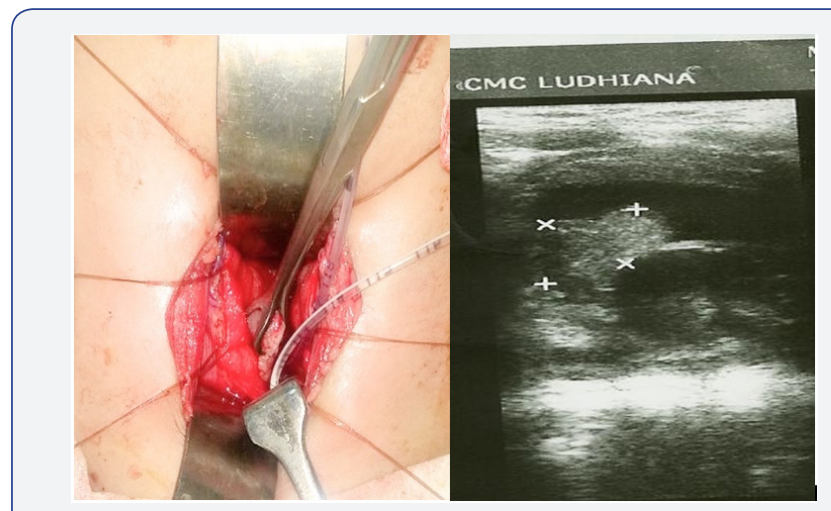

Figure 1: Ultrasonography (USG) showed a round, mobile mass, $22 \times 9 \mathrm{~mm}$ in size at the bladder neck.

\section{Discussion}

Congenital polyps of the male urethra are pedunculated lesions that arise as a defective protrusion of the urethral wall [1]. They occur more often in children and in patients present with bladder outflow obstructions [9]. The investigation of choice is urethrocystoscopy. An ultrasound of the urinary bladder and posterior urethra may reveal a polyp. Histologically, the polyps are composed of vessels, muscle and, less frequently, nerves and glands covered by urothelium. There is some controversy over their embryological origins [7-9]. Downs postulated that the polyps resulted from a defective protrusion of the urethral valve [1]. Kuppusami \& Moors [10] suggest that metaplastic epithelial changes had occurred secondary to the estrogen released during gestation. They found similarities between the urethral polyp and verumontanum histology, which consisted of smooth muscle and small glands lined by transitional cell epithelium [10]. Stephens [11] postulated that the polyp is most likely a congenital lesion. Barrie \& Simms [12] believe that the polyp is a response to urinary tract infections; however, most such inflammatory polyps do not occur in children [11]. The absence of glandular elements within the fibrous polyps of most patients distinguishes them from the verumontanum. These polyps arise from the vestiges of Muller's tubercle and then fail to regress [1]. A precise history, physical examination, and uroflowmetry patterns in toilet-trained children can strongly suggest urethral polyps in children. Urinary tract ultrasonography and micturition cystourethrography are the most important examinations for this diagnosis; however, they are not always successfully diagnostic. The final diagnosis must be confirmed by direct video urethrocystoscopy with minimal irrigation flow. Transurethral resection of the urethral polyps is the standard firstline of management [13]. However, when the polyp length is larger than $3 \mathrm{~cm}$, with diameter of $1 \mathrm{~cm}$ or more, it becomes displaced into the bladder, and open transvesical removal may be an acceptable alternative.

\section{Conclusion}

In all children who present with sudden interruptions of their urinary flow and no obvious bladder or urethral stones, urethral polyps must also be kept in mind as a differential diagnosis. The final and definite diagnosis of polyps is made based on the appearance on urethrocystoscopy. The endoscopic resection of the polyp is the treatment of choice; however, transvesical resection is a safe option in large bladder polyps.

\section{References}

1. Downs RA (1970) Congenital polyps of the prostatic urethra: a review of the literature and report of two cases. Br J Urol 42(1): 76-85.

2. Coleburn NH, Hensle TW (1991) Anterior urethral polyp associated with hematuria in six-year-old child. Urology 38(2): 143-144.

3. Redman JF, Robinson CM (1977) Anterior urethral polyp in a child. J Pediatr Surg 12(5): 735-736.

4. Moriya K, Kobayakawa H, Yasumoto R, Maekawa M (1988) Anterior urethral polyps. Br J Urol 62(2): 183.

5. Anandan N, Shetty S, Patil K, Ibrahim AI (1992) Acute urinary retention caused by anterior urethral polyp. Br J Urol 69(3): 321-322.

6. Walsh I, Keane P, Herron B (1993) Benign urethral polyps. Br J Urol 72(6): 937-938.

7. Foster R, Garrett R (1986) Congenital posterior urethral polyps. J Urol 136(3): 670-672.

8. Bagley FH, Davidson AI (1976) Congenital urethral polyp in a child. Br J Urol 48(4): 278.

9. Stueber PJ, Persky L (1969) Solid tumors of the urethra and bladder neck. J Urol 102(2): 205-209.

10. KuppusamiK, Moors D (1968) Fibrous polyp of the verumontanum. Can J Surg 11(3): 388-391.

11. Stephens FD (1955) Urethral obstruction in childhood: the use of urethrography in diagnosis. Aust N Z J Surg 25(2): 89-109.

12. Barrie HJ, Simms DC (1961) Hydronephrosis resulting from obstruction of the urethra bya polyp of the verumontanum. Am J Clin Pathol 36: 356-361.

13. Gleason PE, Kramer SA (1994) Genitourinary polyps in children. Urology 44(1): 106-109. 

(C) This work is licensed under Creative BY

D.10.1908/AJPN.2017.02.555598
Your next submission with Juniper Publishers will reach you the below assets

- Quality Editorial service

- Swift Peer Review

- Reprints availability

- E-prints Service

- Manuscript Podcast for convenient understanding

- Global attainment for your research

- Manuscript accessibility in different formats

( Pdf, E-pub, Full Text, Audio)

- Unceasing customer service

Track the below URL for one-step submission https://juniperpublishers.com/online-submission.php 